\title{
Effect of intercropping madumbe (Colocasia esculenta) and rice (Oryza sativa $L$.) on yield and land productivity under different irrigation water management techniques with effluent water
}

\author{
TI Busari ${ }^{*}$, A Senzanje', AO Odindo² and CA Buckley ${ }^{3}$ \\ 'Bioresources Engineering, School of Engineering, University of KwaZulu-Natal, Private Bag X01, Scottsville 3209, Pietermaritzburg, \\ South Africa \\ ${ }^{2}$ Crop Science, School of Agricultural, Earth and Environmental Sciences, University of KwaZulu-Natal, Private Bag X01, Scottsville 3209, \\ South Africa \\ ${ }^{3}$ Pollution Research Group, Chemical Engineering, School of Engineering, University of KwaZulu-Natal, Durban 4041, South Africa \\ ${ }^{*}$ Current affiliation: \\ Ministry of Agriculture and Rural Development, Department of Agriculture and Engineering Services, Irrigation Engineering Section, \\ Block W, Room 3, Old Jebba Road, Ilorin, Kwara State, Nigeria
}

\begin{abstract}
The need for the optimal use of land, without a yield penalty, in urban and peri-urban (UP) settlements is vital. This study investigated the effect of intercropping madumbe and rice with respect to yield and land productivity when irrigated with anaerobic baffled reactor (ABR) effluent under different irrigation water management techniques. It was hypothesized that intercropping under different irrigation water management techniques has no effect on the yield and land productivity. Field trials were conducted in the 2017 and 2018 cropping seasons with ABR effluent (without fertilizer) at the Newlands Mashu Experimental Site, Newlands East, Durban, South Africa. A randomized complete block design with 3 replications; cropping treatments of sole madumbe, sole rice and madumbe + rice (intercrop) and irrigation treatments of alternate wetting and drying (AWD), continuous flood irrigation (CFI) and wetting without flooding (WWF) was used. Growth and yield parameters at harvest were determined. Thereafter, land equivalent ratio (LER) was calculated to evaluate the productivity of the intercrop. The effect of intercropping was significant $(P<0.05)$ on the total number of irrigation events and total water use. There was a significant reduction $(P<0.05)$ in plant heights of both madumbe and rice at intercrop. However, the effect on plant height for treatment CFI was positive but not significant $(P>0.05)$ for both seasons. A significant $(P<0.05)$ reduction also occurred in the number of madumbe leaves/plant, and panicles/plant and tillers/plant for rice. Intercropping significantly reduced $(P<0.05)$ madumbe corm and rice grain yield over the two seasons relative to sole cropping. LER showed that intercropping madumbe with rice was not more productive $(L E R<1)$ than sole cropping of madumbe. It was concluded that over the two-season period, intercropping madumbe and rice do not yield appreciably under any of the three irrigation management techniques applied and the study hypothesis is thus rejected.
\end{abstract}

\section{INTRODUCTION}

Agriculture in the future must produce more food from a reduced area of land through more effective use of resources with a negligible effect on the environment, so as to satisfy the demand and needs of the growing population (Hobbs et al., 2008). Intercropping is an old practice that is placed on the fringes of a 'modern agriculture', controlled by large areas of sole-cultured, resourceconsuming and high-yielding crops (Brooker et al., 2015; Yang et al., 2011; Zhang et al., 2010a). Intercropping is a farming practice involving two or more crop species, or genotypes, growing together and coexisting for a time (Brooker et al., 2015). This does not necessarily mean that crops can be planted simultaneously, but for two or more crops to be together in one field, throughout their growing season or in a timeframe. It is, therefore, possible to plant at different times (Dariush et al., 2006; Mousavi and Eskandari, 2011). Intercropping could be a means of addressing some of the main problems related to modern farming, such as pathogen and pest accumulation, environmental deterioration and degradation of soil (Brooker et al., 2015; Rusinamhodzi et al., 2012) thereby promoting more sustainable and productive agriculture (Dordas et al., 2012). The intercropping strategy could consist of a combination of annual/annual; annual/perennial; or perennial/perennial crops (Eskandari, 2012). According to Mousavi and Eskandari (2011), intercropping is categorized as row, mixed, strip and relay. The advantages of intercropping over sole cropping include conservation of soil, promotion of resistance to lodging, yield advantage, and control of weeds (Takim, 2012). Successful intercropping must take into consideration the maturity date of the crop, plant compatibility, planting density (plant architecture) and time of planting (Seran and Brintha, 2010).

The demand for freshwater is increasing; therefore, higher quality water is conserved for domestic use whereas that of lesser quality is suggested for irrigation (Al-Rashed \& Sherif, 2000). Municipal wastewater is considered an attractive source for irrigation because it is less expensive and is considered a means of wastewater disposal which helps to reduce pollution (Al-Rashed and

\section{CORRESPONDENCE}

TI Busari

\section{EMAIL}

bitbabadudu1@gmail.com

\section{DATES}

Received: 11 February 2019

Accepted: April 2020

\section{KEYWORDS}

ABR

alternate wetting and drying (AWD) continuous flood irrigation (CFI) land equivalent ratio (LER) wetting without flooding (WWF)

\section{COPYRIGHT}

(C) The Author(s)

Published under a Creative Commons Attribution 4.0

International Licence (CC BY 4.0) 
Sherif, 2000). Furthermore, it is a valuable source of organic matter and plant nutrients necessary for maintaining fertility and productivity. Nevertheless, water reuse for irrigation may possibly generate environmental problems when not properly managed (Kiziloglu et al., 2008). Appropriate water management for irrigation is of utmost importance to preserve water resources both quantitatively and qualitatively in order to produce more food with the available water (Mermoud et al., 2005). The anaerobic baffled reactor (ABR) plays a role in wastewater treatment and recycling with its creative construction and outstanding performance (Zhu et al., 2015). Decentralized wastewater treatment systems (DEWATS) are widely used in both developing and developed countries, work with little or no energy input, and are reliable and robust. Limited sludge is produced, the operation and maintenance $(\mathrm{O} \& \mathrm{M})$ requirements, and the requirement for highly skilled personnel are low. Risks associated with system failure are reduced and wastewater reuse opportunities increased (Singh et al., 2009). ABR effluent contains mineral elements such as phosphorus and nitrogen, which are significant for plant growth, whereas eutrophication and loss of aquatic life can result when the effluent is emptied into water bodies. Effluents from ABR have been proven to meet the requirements for irrigation with regard to the removal of organics such as BOD or COD for reuse (recycling) in agriculture (Musazura et al., 2015b). The rich nutrient content, e.g., ammonia and phosphorus, present in the effluents may be considered a valuable resource from an agricultural perspective (Musazura et al., 2015a). Heavy metals are of lesser concern for irrigation when using treated domestic effluent as a source of recycled water because they are effectively removed during common treatment processes (Toze, 2006). The majority of the metal content of raw sewage ends up in the sludge settlement partition (Toze, 2006).

Alternate wetting and drying (AWD) is a water-saving irrigation technique which aims to reduce the total amount of irrigation applied in a season. This is done by optimizing the frequency, duration, and intensity of irrigation applications in a way that crop productivity is not endangered by the decrease in total irrigation water (Moya et al., 2004). Irrigated fields with a ponding water layer of 5 to $15 \mathrm{~cm}$ during the growing season are referred to as conventional flood irrigation (CFI) (Bindraban et al., 2006). The $100 \%$ saturated condition is another irrigation management technique (Ruíz-Sánchez et al., 2011), referred to as wetting without flooding (WWF).

Madumbe is a relegated tuber food crop. Its neglect as a food crop has resulted in food insecurity; consequently, its production will play an important role in contributing to improved food security (Kamwendo and Kamwendo, 2014). It has occupied $14^{\text {th }}$ position as the most consumed vegetable globally, yet has received inadequate scientific research attention from either agricultural or academic institutions, and is therefore classified as a neglected and underutilized crop species (Kamwendo and Kamwendo, 2014; Tumuhimbise, 2015). Rice, in the family Poaceaee (grasses), is the major source of food for half of the world's populace, including thousands of families in Sub-Saharan Africa (SSA), and is also the principal water user in agriculture (Lampayan et al., 2015). Imports account for about $40 \%$ of rice consumed in Africa, which exposes Africa to potential global market shocks or food crises (Seck et al., 2010).

There are no reported studies investigating the effect of different irrigation water management techniques using ABR effluent on the growth and yield of either madumbe or rice. There are also no reports of an intercrop of madumbe with rice under different irrigation water management techniques in terms of yield and land productivity, using treated domestic effluent. This study, therefore, evaluated the effect of intercropping madumbe and rice on growth, yield and land productivity under different irrigation water management techniques with ABR effluent water. It was hypothesized that intercropping under different irrigation water management techniques has no effect on the yield and land productivity.

\section{METHODS}

\section{Site description}

Field trials were carried out at Newlands-Mashu Research site $\left(29^{\circ} 46^{\prime} \mathrm{S}\right.$ and $\left.30^{\circ} 58^{\prime} \mathrm{E}\right)$, located at Newlands East, Durban, KwaZulu-Natal Province, Republic of South Africa (Fig. 1).

The trials were carried out over two seasons (2017 winter and 2018 summer). The soil textural classification was a clay loam. It is a humid subtropical climate with hot and humid summers and pleasantly warm and dry winters, which are snow- and frost-free. It has an annual rainfall of $1009 \mathrm{~mm}$. The average temperature in summer ranges around $24^{\circ} \mathrm{C}$, while in winter the average temperature is $17^{\circ} \mathrm{C}$ (Table 1 ).

\section{Planting material}

The madumbe landrace was obtained from Umbumbulu rural district $\left(29^{\circ} 36^{\prime}\right.$ S; $\left.30^{\circ} 25^{\prime} \mathrm{E}\right)$ in KwaZulu-Natal Province, South Africa, and rice seeds, FARO 44, was obtained from Ilorin, through an accredited supplier, Premier seeds $\left(8^{\circ} 30^{\prime} \mathrm{N} ; 5^{\circ} 00^{\prime} \mathrm{E}\right)$, in the north-central part of Nigeria. Madumbe was planted in July

Table 1. Average temperature, relative humidity, and rainfall at the experimental site

\begin{tabular}{|c|c|c|c|c|c|c|c|}
\hline \multirow[t]{2}{*}{ Month } & \multicolumn{3}{|c|}{ Average temp. $\left({ }^{\circ} \mathrm{C}\right)$} & \multicolumn{3}{|c|}{ Relative humidity (\%) } & \multirow[t]{2}{*}{ Rainfall (mm) } \\
\hline & Max & Min & Ave. & Max & Min & Ave. & \\
\hline Sept. 2017 & 25.58 & 14.12 & 19.85 & 94.27 & 48.22 & 71.25 & 30.36 \\
\hline Oct. 2017 & 27.03 & 15.35 & 21.19 & 93.99 & 47.31 & 70.65 & 54.10 \\
\hline Nov. 2017 & 26.64 & 16.42 & 21.53 & 94.15 & 50.36 & 72.26 & 70.44 \\
\hline Dec. 2017 & 28.27 & 19.39 & 23.83 & 94.93 & 56.96 & 75.95 & 86.61 \\
\hline Jan. 2018 & 29.98 & 20.20 & 25.09 & 94.92 & 54.29 & 74.60 & 123.28 \\
\hline Feb. 2018 & 30.10 & 19.73 & 24.91 & 95.33 & 53.35 & 74.34 & 70.79 \\
\hline Mar. 2018 & 29.80 & 19.27 & 24.53 & 96.76 & 54.65 & 75.71 & 88.73 \\
\hline Apr. 2018 & 28.19 & 15.98 & 22.09 & 95.92 & 47.05 & 71.49 & 12.53 \\
\hline May 2018 & 27.41 & 12.67 & 20.04 & 96.99 & 41.88 & 69.44 & 75.35 \\
\hline June 2018 & 26.13 & 9.64 & 17.88 & 95.34 & 33.65 & 64.49 & 2.79 \\
\hline July 2018 & 24.98 & 7.92 & 16.45 & 93.98 & 29.55 & 61.77 & 2.54 \\
\hline
\end{tabular}




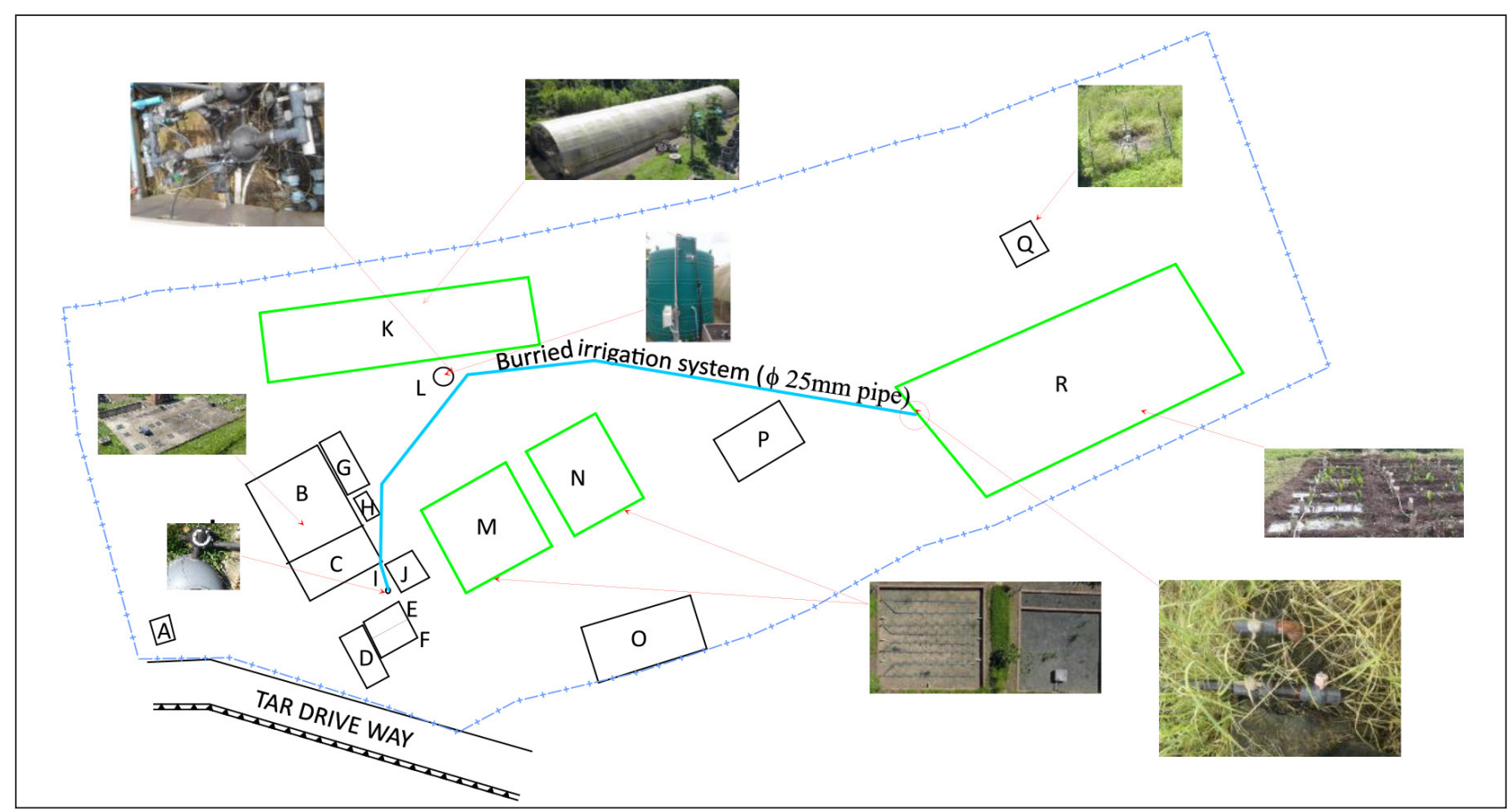

Figure 1. Layout of the study area at Newlands East, Durban, South Africa LEGEND

$\begin{array}{ll}\text { A } & \text { Security post } \\ C & \text { Anaerobic filter (AF) } \\ E & \text { Membrane wet chamber } \\ G & \text { Sludge drying bed (SDB) } \\ \text { I } & \text { Submersible pump } \\ K & \text { Growing tunnel } \\ M & \text { Vertical flow wetlands (VFW) } \\ O & \text { Office / laboratory } \\ Q & \text { Weather station }\end{array}$

B Anaerobic baffled reactor (ABR)

D Containerised DEWATS container

F Membrane dry chamber

H Switch box

J Siphon chamber

L $\quad$ Effluent JoJo tank \& surface pump

$N \quad$ Horizontal flow wetlands (HFW)

Office / laboratory

Soil preparation shed

Trial field \& effluent points of discharge

2017 (Season 1) and in December 2017 (Season 2), while the rice was planted in September 2017 and February 2018 for Seasons 1 and 2, respectively. Madumbe seedlings raised with freshwater for 2 months were later transferred and transplanted into the prepared field. Seedlings were washed and soaked in salty water for a day. They were then incubated at $30^{\circ} \mathrm{C}$ for another $24 \mathrm{~h}$ to stimulate strong germination, as suggested by Mulbah (2010). Seedlings were raised in a seedbed for 14 days. The rice seeds were later transplanted to join standing madumbe on the same plots at 2 weeks after planting. Relay intercropping was adopted in order not to allow for competition, since madumbe has large heart-shaped leaves that may affect the growth of a grass family crop like rice. The intercropping was 1:1 (1 row of madumbe to 1 row of rice). The intercrop spacing was $0.5 \mathrm{~m}$ while intra-crop spacing was 0.5 for madumbe and $0.25 \mathrm{~m}$ for rice. This gave rise to a population of $40000 \mathrm{plants} / \mathrm{ha}$ for rice and madumbe. Periodic weeding was done and no additional fertilizer was added since the irrigation water contained nutrients such as ammonia and phosphorus. There were no plant diseases identified during the trials; hence, no insecticides were applied. Different scarecrows were used in order to prevent birds' from feeding on the rice. Crop selection, i.e. using crops (madumbe and rice) that must be boiled before eating, and limiting human exposure through choice of wastewater application method are some of the ways to safeguard farm workers and their households when using wastewater in agriculture (Scott et al., 2008). The people working on the farm must use appropriate protective clothing - long gloves and shoes, and practise handwashing with soap. Laborious health training programmes and vaccination against typhoid and hepatitis are worthy of consideration (Scott et al., 2008).

\section{Experimental design}

The experiments (both seasons) were laid out in a randomized complete block design (RCBD), replicated 3 times. Randomization was done using Kutools for Excel software to avoid bias (Kutools, 2017). The component crops were madumbe and rice. The treatments included madumbe and rice sole cropping, and intercrop. The treatment combination is presented in Table 2.

The experimental plots were $3 \times 1.5 \mathrm{~m}$. This resulted in a total of 27 plots (Fig. 2) in the field with 9 plots in a row (block). Each of the plots was separated by bund $(30 \mathrm{~cm}$ wide at the base and

Table 2. Treatment combinations

\begin{tabular}{|c|c|c|}
\hline $\mathbf{S} / \mathbf{N}$ & Treatment code & Treatment detail \\
\hline 1 & AWD-M & $\begin{array}{l}\text { Alternate wetting and drying with } \\
\text { madumbe }\end{array}$ \\
\hline 2 & AWD-R & Alternate wetting and drying with rice \\
\hline 3 & AWD-MR & $\begin{array}{l}\text { Alternate wetting and drying with } \\
\text { madumbe and rice }\end{array}$ \\
\hline 4 & CFI-M & Continuous flooding with madumbe \\
\hline 5 & CFI-R & Continuous flooding with rice \\
\hline 6 & CFI-MR & $\begin{array}{l}\text { Continuous flooding with madumbe and } \\
\text { rice }\end{array}$ \\
\hline 7 & WWF-M & Wetting without ponding with madumbe \\
\hline 8 & WWF-R & Wetting without ponding with rice \\
\hline 9 & WWF-MR & $\begin{array}{l}\text { Wetting without ponding with madumbe } \\
\text { and rice }\end{array}$ \\
\hline
\end{tabular}




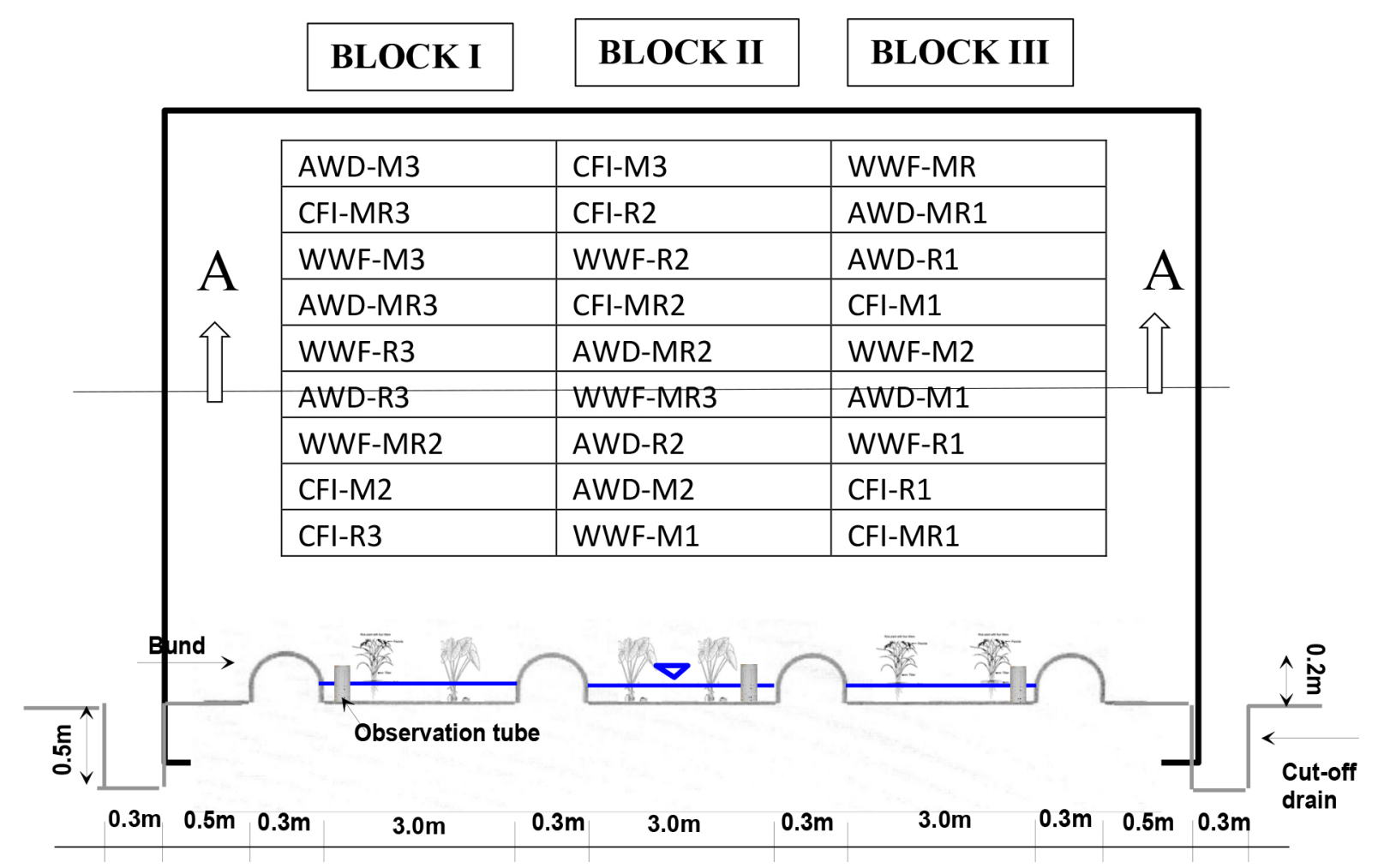

Figure 2. The layout of the field trials (above) and cross-section A-A (below)

$20 \mathrm{~cm}$ high) to isolate them from adjacent plots and to prevent run-on, run-off, lateral-in and lateral-off in each plot. To prevent seepage, polythene sheets $(250 \mu \mathrm{m}$ thickness) were pushed into the soil to a depth of $0.6 \mathrm{~m}$ and also covered the bund. The 0.6 $\mathrm{m}$ depth was adopted with consideration to the root zone depth of madumbe $(0.5 \mathrm{~m})$ and rice $(0.2 \mathrm{~m})$, though Tan et al. (2013), Zhang et al. (2010b), Pascual and Wang (2016) have suggested $0.5 \mathrm{~m}$, Ye et al. (2013) used $0.3 \mathrm{~m}$, and Yao et al. (2012) suggested $0.2 \mathrm{~m}$ as the depth to which to bury the plastic sheeting.

For all the treatments, PVC pipes of $110 \mathrm{~mm}$ diameter and $400 \mathrm{~mm}$ length were installed in the field, keeping $200 \mathrm{~mm}$ above

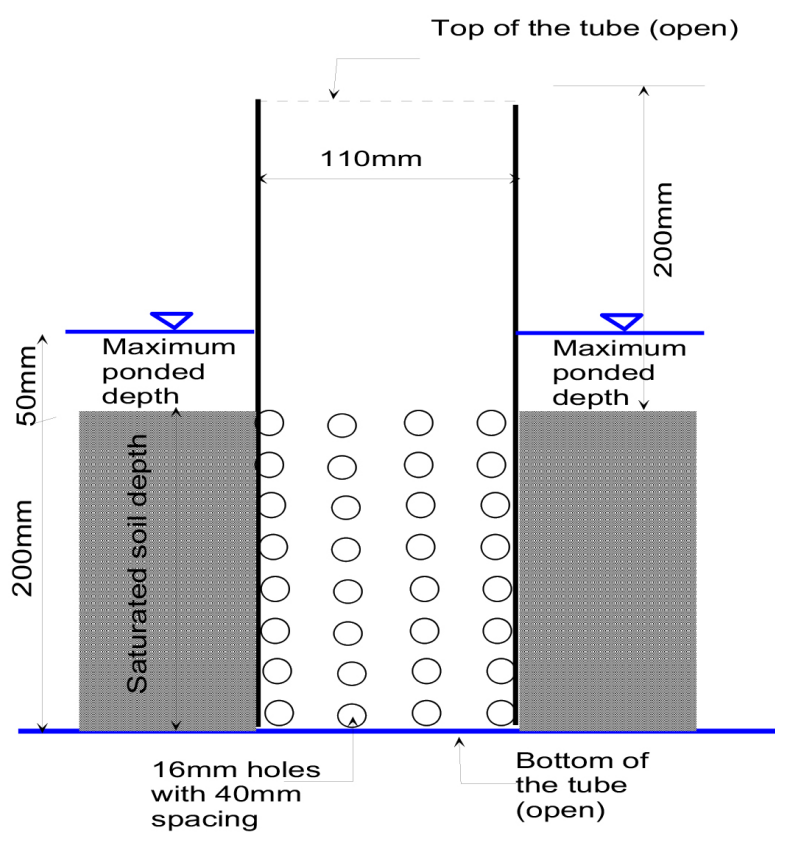

Figure 3. Field water tube/observation well (adopted from Lampayan et al., 2015) the soil and the remaining $200 \mathrm{~mm}$, which was perforated with $16 \mathrm{~mm}$ diameter holes at $40 \mathrm{~mm}$ intervals (Fig. 3), underneath, to measure the depletion of irrigation water in the field and to instruct when to irrigate (Cabangon et al., 2011; Lampayan et al., 2015; Oliver et al., 2008; Price et al., 2013; Ye et al., 2013). Irrigation water was applied through a network of pipes that were installed in the trial field to facilitate irrigation application and measurement. The network contained PVC pipes and fittings of different diameters, ranging from 15 to $25 \mathrm{~mm}$. Water applied in each plot was measured by the level of water inside the observation tube wells (Fig. 3) inserted in each plot. This is dictated by manual observation of the water level in the water observation tube, with the aid of an improvised lightweight foam (polystyrene). The amount of rainfall was obtained from the on-site weather station. Irrigation water was applied when depletion of the water table inside the pipe reached a certain level. The CFI was continuous submergence $(50 \mathrm{~mm}$ standing water); AWD was an application of $50 \mathrm{~mm}$ irrigation water depth when the water level in the pipe fell $150 \mathrm{~mm}$ below the ground level; WWF maintained the same water level in the observation pipe with the ground level of the field plots.

\section{Data collection and analyses}

Quantitative information related to number of irrigation time events, amount of irrigation applied $(\mathrm{mm})$, total water use (irrigation plus rainfall $-\mathrm{mm})$, plant height $(\mathrm{cm})$, number of leaves per plant, corm yield $(\mathrm{t} / \mathrm{ha})$ for madumbe, plant height $(\mathrm{cm})$, number of tillers per plant, number of panicles per plant at harvest, and grain yield (t/ha) for rice were collected and analysed for both seasons to determine the effect of intercropping and irrigation water management techniques with the use of ABR effluent as irrigation water. The plant heights for both crops were measured with the aid of a scale rule while leaf, tiller and panicle number per plant were counted manually. The yield of madumbe was determined according to the method described by Gebre et al. (2015). Three samples of harvested rice grains were randomly obtained from each replication; initial 
weights were recorded. The final weights were recorded after oven drying at $70^{\circ} \mathrm{C}$ for $72 \mathrm{~h}$; subsequently, the grain yield was adjusted to $16 \%$ seed moisture content. Land productivity of the intercrop was determined using the land equivalent ratio (LER) as described by Mead and Willey (1980), Ibeawuchi (2007) and Chimonyo et al. (2016):

$$
\mathrm{LER}=L_{A}+L_{B}=\frac{Y_{A}}{S_{A}}+\frac{Y_{B}}{S_{B}}
$$

where $L_{\mathrm{A}}$ and $L_{\mathrm{B}}$ are the partial LERs of madumbe and rice, respectively, $Y_{\mathrm{A}}$ and $Y_{\mathrm{B}}$ are the intercrop yields of madumbe and rice, respectively, and $S_{\mathrm{A}}$ and $S_{\mathrm{B}}$ are their respective sole crop yields. When LER $>1$, it signals yield advantage, and LER $<1$ a yield disadvantage. Data were subjected to a normality test using both skewness and kurtosis for numerical outputs and normal Q-Q plots for visual outputs. The two methods showed that the variables were approximately normally distributed. The data was then analysed using the ANOVA algorithm in GenStat (Version 18) (VSN International Ltd, UK). Duncan's Multiple Range Test (DMRT) was used for mean separation at the $5 \%$ level of significance.

\section{RESULTS AND DISCUSSION}

\section{Characterization of ABR effluent}

ABR effluent does not meet the minimum standards for disposal into the environment and water bodies with reference to chemical oxygen demand (COD) $(<400 \mathrm{mg} / \mathrm{L})$, total $\mathrm{N}$ (5-30 mg/L), EC (0-3 dS/m) and total coliforms. However, it constantly met the required standard for irrigation with regard to the removal of organics for reuse in agriculture. The COD indicates the ability of water to deplete oxygen and reduce compounds such as nitrates. The average $\mathrm{pH}$ in the ABR was 7.27 which allows for the activity of bacteria to act on the degradation of organic waste. The range of 6.5 to 8.4 is the $\mathrm{pH}$ requirement for irrigation water. The $\mathrm{pH}$ level of irrigation water affects nutrient availability, corrosiveness for irrigation pipes and crop quality, especially in sensitive species (Bame et al., 2014). Total suspended solids (TSS) can affect the physical properties of soil, and cause salinity problems and clogging. Effluent TSS was 82 $\mathrm{mg} / \mathrm{L}$ and a concentration of less than $100 \mathrm{mg} / \mathrm{L}$ is recommended for irrigation use. Table 3 presents the characteristics of the ABR effluent.

Table 3. ABR effluent characteristics

\begin{tabular}{|c|c|c|c|c|}
\hline Parameters & Units & Mean & SD & Range \\
\hline Ammonium-N $\left(\mathrm{NH}_{4}^{+}-\mathrm{N}\right)$ & $\mathrm{mg} / \mathrm{L})$ & 58.45 & \pm 0.89 & $43.73-67.57$ \\
\hline Nitrite- $\mathrm{N}\left(\mathrm{NO}_{2}^{-}{ }^{-} \mathrm{N}\right)$ & $\mathrm{mg} / \mathrm{L})$ & 0.53 & \pm 0.01 & $0.18-1.00$ \\
\hline Nitrate- $\mathrm{N}\left(\mathrm{NO}_{3}{ }^{-}-\mathrm{N}\right)$ & $\mathrm{mg} / \mathrm{L})$ & 0.30 & \pm 0.07 & $0.10-0.47$ \\
\hline Total Kjeldahl N (TKN) & $\mathrm{mg} / \mathrm{L})$ & 62.91 & \pm 0.87 & $46.93-76.20$ \\
\hline Total nitrogen (TN) & $\mathrm{mg} / \mathrm{L})$ & 67.67 & \pm 1.37 & $53.67-76.00$ \\
\hline Orthophosphate $\left(\mathrm{PO}_{4}^{3-}\right)$ & $\mathrm{mg} / \mathrm{L})$ & 18.19 & \pm 0.18 & $14.80-22.23$ \\
\hline Chemical oxygen demand (CODt) & $\mathrm{mg} / \mathrm{L})$ & 276.60 & \pm 5.03 & $222.67-295.00$ \\
\hline Total suspended solids (TSS) & $\mathrm{mg} / \mathrm{L})$ & 82.00 & \pm 2.03 & $67.78-123.33$ \\
\hline Dissolved oxygen (DO) & $\mathrm{mg} / \mathrm{L})$ & 1.37 & \pm 0.05 & $0.22-3.51$ \\
\hline Alkalinity & $\mathrm{mg} / \mathrm{L})$ & 6.98 & \pm 0.19 & $5.56-7.87$ \\
\hline E.coli & $\mathrm{cfu} / \mathrm{mL})$ & 2600.00 & \pm 700.00 & $2000.00-3400.00$ \\
\hline $\mathrm{pH}$ & & 7.27 & \pm 0.05 & $7.19-7.38$ \\
\hline Electrical conductivity (EC) & $\mathrm{S} / \mathrm{m}$ & 93.22 & \pm 0.83 & $71.57-107.90$ \\
\hline
\end{tabular}

Table 4. Effect of intercropping on the number of irrigation events, amount of irrigation water applied, and total water use under different irrigation water management techniques using ABR effluent

\begin{tabular}{|c|c|c|c|c|}
\hline Season & Treatments & Number of irrigation events & Amount of irrigation (mm) & Total water use (mm) \\
\hline \multirow[t]{6}{*}{2017} & AWD-M & $18.00^{\mathrm{a}}$ & $847.00^{\mathrm{a}}$ & $1197.00^{a}$ \\
\hline & AWD-MR & $25.00^{\mathrm{b}}$ & $1194.00^{b}$ & $1544.00^{\mathrm{b}}$ \\
\hline & CFI-M & $66.67^{d}$ & $1684.00^{c}$ & $2034.00^{c}$ \\
\hline & CFI-MR & $78.67^{f}$ & $2221.00^{e}$ & $2571.00^{e}$ \\
\hline & WWF-M & $63.00^{c}$ & $1540.00^{c}$ & $1891.00^{c}$ \\
\hline & WWF-MR & $75.67^{e}$ & $2004.00^{d}$ & $2354.00^{d}$ \\
\hline \multirow[t]{6}{*}{2018} & AWD-M & $31.00^{\mathrm{a}}$ & $1498.00^{\mathrm{a}}$ & $1743.00^{\mathrm{a}}$ \\
\hline & AWD-MR & $39.00^{b}$ & $1949.00^{\mathrm{a}}$ & $2194.00^{\mathrm{a}}$ \\
\hline & CFI-M & $135.00^{\mathrm{cd}}$ & $3952.00^{\mathrm{cd}}$ & $4197.00^{c d}$ \\
\hline & CFI-MR & $143.00^{\mathrm{e}}$ & $4414.00^{d}$ & $4659.00^{d}$ \\
\hline & WWF-M & $134.00^{c}$ & $3290.00^{\mathrm{b}}$ & $3535.00^{\mathrm{b}}$ \\
\hline & WWF-MR & $137.30^{d}$ & $3745.00^{\mathrm{bc}}$ & $3990.00^{b c}$ \\
\hline
\end{tabular}

Numbers with different letters in the same column and treatment within a season differ significantly at the 5\% level of significance 


\section{Irrigation}

Intercropping had a significant $(P<0.05)$ effect on the number of irrigation events, amount of irrigation water applied, and total water use for both the 2017 and 2018 growing seasons (Table 4). The effect of irrigation water management techniques was also significant $(P<0.05)$ on the number of irrigation events, amount of irrigation water applied and total water use for both seasons (Table 4). The number of irrigation events was higher in intercropping relative to sole cropping. The number of irrigation events increased from sole to intercropping by $28 \%$ for AWD, $15 \%$ for CFI and $17 \%$ for WWF in 2017, while it increased by $21 \%$ (AWD), 6\% (CFI) and 2\% for WWF in 2018. By treatments, AWD had the lowest number of irrigation events and lowest total water use (irrigation and rainfall) and CFI had the highest number of irrigation events and highest total water use for both seasons. There was an increase in the total water use when comparing intercropping with sole cropping, meaning intercropping has higher total water use. This was also confirmed with reference to different irrigation management techniques.

\section{Growth of madumbe}

The plant height of madumbe for both seasons was significantly negatively affected $(P<0.05)$ by intercropping in treatments AWD and WWF. However, the effect on plant height at harvest for treatment CFI was positive, though not significant $(P>0.05)$, for both seasons (Table 5). The number of leaves per plant was also significantly negatively affected $(P<0.05)$ by intercropping. The plant height at harvest for madumbe under intercropping resulted in about a $17 \%$ reduction for AWD and a $6 \%$ reduction for WWF in 2017, while a $24 \%$ reduction for AWD and $14 \%$ reduction for WWF in the 2018 planting season took place relative to sole cropping. However, there was an exception for treatment CFI, which recorded $11 \%$ and $2 \%$ increases in 2017 and 2018 , respectively. This could be attributed to continuous ponded conditions plus intercropping which do not permit weed growth (Takim, 2012). Madumbe is sensitive to weed competition over most of its growing cycle (Gurnah, 1985). The effect of intercropping also reduced the number of leaves per plant (madumbe) when compared with sole cropping. The reductions were in the order of $21 \%$ (AWD), $13 \%$ (CFI) and $6 \%$ (WWF) in the 2017 planting season. There was a slight difference in 2018 when the reductions were in the order of $18 \%$ (AWD), $17 \%$ (CFI) and

Table 5. Effect of intercropping on the growth of madumbe under different irrigation water management techniques using ABR effluent

\begin{tabular}{lccc}
\hline Season & Treatments & $\begin{array}{c}\text { Plant height } \\
(\mathbf{c m})\end{array}$ & $\begin{array}{c}\text { Number of } \\
\text { leaves/ } \\
\text { plant }\end{array}$ \\
\hline 2017 & AWD-M & $99.80^{\mathrm{bc}}$ & $14.44^{\mathrm{bc}}$ \\
& AWD-MR & $82.90^{\mathrm{a}}$ & $11.72^{\mathrm{a}}$ \\
& CFI-M & $101.80^{\mathrm{bc}}$ & $14.78^{\mathrm{c}}$ \\
CFI-MR & $115.30^{\mathrm{c}}$ & $13.38^{\mathrm{b}}$ \\
& WWF-M & $103.70^{\mathrm{bc}}$ & $14.89^{\mathrm{c}}$ \\
\hline 2018 & $98.30^{\mathrm{b}}$ & $14.05^{\mathrm{bc}}$ \\
\hline WWF-MR & $114.70^{\mathrm{bc}}$ & $11.44^{\mathrm{b}}$ \\
& AWD-M & $87.40^{\mathrm{a}}$ & $9.38^{\mathrm{a}}$ \\
& AWD-MR & $116.80^{\mathrm{c}}$ & $11.56^{\mathrm{b}}$ \\
& CFI-M & $118.80^{\mathrm{c}}$ & $9.71^{\mathrm{a}}$ \\
& CFI-MR & $118.30^{\mathrm{c}}$ & $11.56^{\mathrm{b}}$ \\
\hline WWF-M & $101.30^{\mathrm{ab}}$ & $9.16^{\mathrm{a}}$ \\
\hline Wumbers with different letters in the same column and treatment within \\
a season differ significantly at the 5\% level of significance
\end{tabular}

25\% (WWF). The two seasons exhibited a similar trend under the same irrigation technique. The results obtained in this study are consonant with the findings of Mabhaudhi and Modi (2014).

\section{Growth of rice}

Intercropping had a significant negative effect $(P<0.05)$ on plant height, panicle number per plant and tiller number per plant; rice in the intercrop was shorter and had fewer panicle and tiller numbers compared with the sole crop (Table 6). The plant height of rice at harvest in all treatments showed a $38.5 \%$ reduction when compared with rice grown as a sole crop, for both seasons. The reduction in the number of tillers per plant ranges between an average of 75\% (2017) and 64\% (2018 season). The number of panicles per plant at harvest was reduced by $78 \%$ in 2017 and $84 \%$ in the 2018 season, due to intercropping. Intercropping in this study resulted in shorter plant heights, fewer leaf numbers per plant, tiller numbers per plant and number of panicles per plant compared with sole cropping. The work of Sagoe et al. (2004), to the contrary, found that rice plant height and tiller number were higher in the rice-taro intercrop under a tropical (Ghana) climate characterized by the wet and dry season of a typical West African country. This could be as a result of many factors, such as species of component crops, type of intercropping, season, method of irrigation, nature of the soil, and nutrients content of the water. The results of the present study may suggest inter-specific competition for resources such as space, light, and nutrients (Mabhaudhi and Modi, 2014). There could also be possible effects of leaf architecture (shading) on rice from the adjacent madumbe plants with broad heart-shaped leaves.

\section{Yield and intercrop productivity}

Intercropping had a significant effect/reduction $(P<0.05)$ on the corm yield and grain yield of both component crops in both seasons (Table 6). The study showed that mono-cropping of either component crop consistently yielded higher than intercropping. This study showed that mono-cropping of madumbe consistently yielded more than madumbe-rice intercrop; this is in agreement with the research of Sagoe et al. (2004) that found that final taro yields were reduced in the ricetaro intercrop. There was no competition for resources, such as ABR effluent-water, space and light in the madumbe sole cropping as compared to the intercrop. The two crops (tuber and

Table 6. Effect of intercropping on the growth of rice under different irrigation water management techniques using ABR effluent

\begin{tabular}{ccccc}
\hline Season & Treatments & $\begin{array}{c}\text { Plant } \\
\text { height } \\
(\mathbf{c m})\end{array}$ & $\begin{array}{c}\text { Number } \\
\text { of tillers/ } \\
\text { plant }\end{array}$ & $\begin{array}{c}\text { Number of } \\
\text { panicles/ } \\
\text { plant }\end{array}$ \\
\hline 2017 & AWD-R & $107.08^{\mathrm{b}}$ & $113.08^{\mathrm{d}}$ & $38.75^{\mathrm{c}}$ \\
& AWD-MR & $67.08^{\mathrm{a}}$ & $28.50^{\mathrm{b}}$ & $8.67^{\mathrm{a}}$ \\
& CFI-R & $121.33^{\mathrm{c}}$ & $91.58^{\mathrm{c}}$ & $29.08^{\mathrm{b}}$ \\
& CFI-MR & $74.08^{\mathrm{a}}$ & $26.42^{\mathrm{b}}$ & $6.67^{\mathrm{a}}$ \\
& WWF-R & $110.33^{\mathrm{b}}$ & $90.83^{\mathrm{c}}$ & $24.75^{\mathrm{b}}$ \\
& WWF-MR & $69.75^{\mathrm{a}}$ & $20.33^{\mathrm{a}}$ & $5.25^{\mathrm{a}}$ \\
\hline \multirow{2}{*}{2018} & AWD-R & $122.80^{\mathrm{b}}$ & $83.42^{\mathrm{c}}$ & $61.42^{\mathrm{c}}$ \\
& AWD-MR & $72.60^{\mathrm{a}}$ & $33.69^{\mathrm{b}}$ & $11.03^{\mathrm{a}}$ \\
& CFI-R & $131.00^{\mathrm{b}}$ & $79.75^{\mathrm{c}}$ & $51.75^{\mathrm{b}}$ \\
& CFI-MR & $77.50^{\mathrm{a}}$ & $29.53^{\mathrm{b}}$ & $7.92^{\mathrm{a}}$ \\
& WWF-R & $125.30^{\mathrm{b}}$ & $79.50^{\mathrm{c}}$ & $47.42^{\mathrm{b}}$ \\
& WWF-MR & $74.20^{\mathrm{a}}$ & $22.96^{\mathrm{a}}$ & $6.55^{\mathrm{a}}$ \\
\hline
\end{tabular}

Numbers with different letters in the same column and treatment within a season differ significantly at the $5 \%$ level of significance 
grass family) are both water- and nutrient-loving crops, which could lead to resource competition; hence, this may be the reason for the negative effect on the yield of both crops at intercrop. One of the criteria for assessing the viability of intercropping is to determine if the yield of the main crop will not be affected (Mabhaudhi and Modi, 2014). This criterion assumes that any yield from the second crop is acceptable. This study sought to determine if intercropping madumbe with rice would not affect madumbe yield; therefore, any yield of rice achieved would be considered acceptable. The yield of rice obtained in all cases in the intercrop (Table 7) was not comparable to the results of rice grown as a stand-alone crop. This is in agreement with the study of Sagoe et al. (2004) that reported reduced yield of rice in a rice-taro intercrop. Introducing rice reduced the total taro yield by about $24 \%-32 \%$ (Sagoe et al., 2004). Row intercropping adopted by Okwuowulu et al. (2000) resulted in higher relative yield totals of cocoyam (madumbe) for the two varieties used but reduced the yield of rice in combinations. The results of this study are also consistent with the work of Enesi et al. (2018), which found that intercropping of tuber (yam) with maize reduced tuber yield by an average of $40 \%$ over 3 years across all yam densities. Maize grain yield was greater in the mono-crop than intercrop.

The productivity of the intercrop was evaluated using the LER and the results are presented in Table 8. This study showed that intercropping madumbe with rice does not signify a better combination option since the average LER over the two seasons was less than 1, unlike the LER obtained by Sagoe et al. (2004) which signified a better choice in terms of land resource use. When LER is greater than 1 or more it signals yield advantage, and a ratio of less than 1 is a yield disadvantage (Ibeawuchi, 2007). Other benefits of intercropping, such as less weeding as compared to mono-cropping, were more visible at the site during the experimental trials.

Table 7. Effect of intercropping on the yield of madumbe/rice under different irrigation water management techniques using ABR effluent

\begin{tabular}{cccc}
\hline Season & Treatments & $\begin{array}{c}\text { Madumbe corm } \\
\text { yield }\left(\mathbf{t} \cdot \mathbf{h a}^{-1}\right)\end{array}$ & $\begin{array}{c}\text { Rice grain } \\
\text { yield }\left(\mathbf{t} \cdot \mathbf{h a} \mathbf{a}^{-1}\right)\end{array}$ \\
\hline 2017 & AWD & $5.02^{\mathrm{c}}$ & $5.62^{\mathrm{c}}$ \\
& AWD-MR & $4.20^{\mathrm{b}}$ & $1.20^{\mathrm{a}}$ \\
& CFI & $3.96^{\mathrm{b}}$ & $5.39^{\mathrm{c}}$ \\
& CFI-MR & $3.29^{\mathrm{a}}$ & $1.18^{\mathrm{a}}$ \\
& WWF & $7.52^{\mathrm{d}}$ & $3.86^{\mathrm{b}}$ \\
& WWF-MR & $4.96^{\mathrm{c}}$ & $0.84^{\mathrm{a}}$ \\
\hline 2018 & AWD & $7.34^{\mathrm{e}}$ & $6.38^{\mathrm{c}}$ \\
& AWD-MR & $4.46^{\mathrm{b}}$ & $1.67^{\mathrm{a}}$ \\
& CFI & $5.61^{\mathrm{c}}$ & $6.36^{\mathrm{c}}$ \\
& CFI-MR & $2.73^{\mathrm{a}}$ & $1.51^{\mathrm{a}}$ \\
& WWF & $9.84^{\mathrm{f}}$ & $4.12^{\mathrm{b}}$ \\
& WWF-MR & $6.96^{\mathrm{d}}$ & $1.00^{\mathrm{a}}$ \\
\hline
\end{tabular}

Numbers with different letters in the same column and treatment within a season differ significantly at the $5 \%$ level of significance

Table 8. LER under different irrigation management techniques using ABR effluent

\begin{tabular}{lccc}
\hline Treatments & LER 2017 & LER 2018 & Average LER \\
\hline AWD & 1.05 & 0.87 & 0.96 \\
CFI & 1.05 & 0.72 & 0.89 \\
WWF & 0.88 & 0.95 & 0.92 \\
\hline
\end{tabular}

\section{CONCLUSIONS}

Crop production will have to produce more food from limited land space by making more efficient use of natural resources and with an insignificant impact on the environment. This is the only way in which food production can keep up with demand and land productivity for future generations. Madumbe and rice grown as sole crops performed better than their intercrop. The number of irrigations and the total amount of water used were higher under intercropping. Intercropping madumbe with rice resulted in a significant reduction in all parameters measured at different irrigation treatments with the exception of madumbe plant height under CFI treatments, though this was not significant. There was a consistent yield reduction in both component crops with intercropping. It could, therefore, be concluded that a madumberice intercrop was not productive over the two trial seasons considered, hence, this intercrop is not encouraged based on the outcome of this study and the hypothesis that intercropping under different irrigation water management techniques has no effect on the yield and land productivity" should be rejected. Further studies should be carried out to investigate in detail the effect of water quality (using treated, raw wastewater and municipal water supply) on the intercrop of rice and madumbe.

\section{ACKNOWLEDGMENTS}

This research was funded by the University of KwaZulu-Natal and eThekwini Water and Sanitation (EWS) unit of the eThekwini Municipality, Durban, South Africa, and is acknowledged.

\section{REFERENCES}

AL-RASHED MF and SHERIF MM (2000) Water resources in the GCC countries: an overview. Water Resour. Manage. 14 (1) 59-75. https:// doi.org/10.1023/A:1008127027743

BAME I, HUGHES J, TITSHALL L and BUCKLEY C (2014) The effect of irrigation with anaerobic baffled reactor effluent on nutrient availability, soil properties and maize growth. Agric. Water Manage. 134 50-59. https://doi.org/10.1016/j.agwat.2013.11.011

BINDRABAN P, HENGSDIJK H, CAO W, SHI Q, THIYAGARAJAN T, VAN DER KROGT W and WARDANA I (2006) Transforming inundated rice cultivation. Water Resour. Dev. 22 (1) 87-100. https:// doi.org/10.1080/07900620500405338

BROOKER RW, BENNETT AE, CONG WF, DANIELL TJ, GEORGE TS, HALLETT PD, HAWES C, IANNETTA PP, JONES HG and KARLEY AJ (2015) Improving intercropping: a synthesis of research in agronomy, plant physiology and ecology. New Phytol. 206 (1) 107117. https://doi.org/10.1111/nph.13132

CABANGON R, CASTILlO E and TUONG T (2011) Chlorophyll meter-based nitrogen management of rice grown under alternate wetting and drying irrigation. Field Crops Res. 121 (1) 136-146. https://doi.org/10.1016/j.fcr.2010.12.002

CHIMONYO V, MODI A and MABHAUDHI T (2016) Water use and productivity of a sorghum-cowpea-bottle gourd intercrop system. Agric. Water Manage. 165 82-96. https://doi.org/10.1016/j. agwat.2015.11.014

DARIUSH M, AHAD $M$ and MEYSAM O (2006) Assessing the land equivalent ratio (LER) of two corn [Zea mays L.] varieties intercropping at various nitrogen levels in Karaj, Iran. J. Cent. Eur. Agric. 7 (2) 359-364.

DORDAS CA, VLACHOSTERGIOS DN and LITHOURGIDIS AS (2012) Growth dynamics and agronomic-economic benefits of pea-oat and pea-barley intercrops. Crop Pasture Sci. 63 (1) 45-52. https://doi.org/10.1071/CP11181

ENESI RO, HAUSER S, LOPEZ-MONTEZ A and OSONUBI O (2018) Yam tuber and maize grain yield response to cropping system intensification in south-west Nigeria. Arch. Agron. Soil Sci. 64 (7) 953-966. https://doi.org/10.1080/03650340.2017.1404580

ESKANDARI H (2012) Yield and quality of forage produced in intercropping of maize (Zea mays) with cowpea (Vigna sinensis) and mungbean (Vigna radiata) as double cropped. J. Basic Appl. Sci. Res. 2 (1) 93. 
GEBRE A, TESFAYE B and MENGESHA KASSAHUN B (2015) Effect of corm size and plant population density on corm yield of Taro (Colocasia esculenta L.). Int. J. Adv. Biol. Biomed. Res. 3 (4) 405-412. https://doi.org/10.18869/IJABBR.2015.405

GURNAH A (1985) Effects of weed competition at different stages of growth on the yield of taro. Field Crops Res. 10 283-289. https://doi. org/10.1016/0378-4290(85)90034-6

HOBBS PR, SAYRE K and GUPTA R (2008) The role of conservation agriculture in sustainable agriculture. Phil. Trans. R. Soc. Lond. B Biol. Sci. 363 (1491) 543-555. https://doi.org/10.1098/rstb.2007.2169

IBEAWUCHI I (2007) Intercropping - a food production strategy for the resource poor farmers. Nat. Sci. 5 (1) 46-59.

KAMWENDO G and KAMWENDO J (2014) Indigenous knowledgesystems and food security: some examples from Malawi. J. Hum Ecol. 48 (1) 97-101. https://doi.org/10.1080/09709274.2014.11906778

KIZILOGLU F, TURAN M, SAHIN U, KUSLU Y and DURSUN A (2008) Effects of untreated and treated wastewater irrigation on some chemical properties of cauliflower (Brassica olerecea L. var. botrytis) and red cabbage (Brassica olerecea L. var. rubra) grown on calcareous soil in Turkey. Agric. Water Manage. 95 (6) 716-724 https://doi.org/10.1016/j.agwat.2008.01.008

KUTOOLS (2017 Kutools for Excel Software. $16.50 \mathrm{ed.}$

LAMPAYAN RM, REJESUS RM, SINGLETON GR and BOUMAN BA (2015) Adoption and economics of alternate wetting and drying water management for irrigated lowland rice. Field Crops Res. 170 95-108. https://doi.org/10.1016/j.fcr.2014.10.013

MABHAUDHI T and MODI A (2014) Intercropping Taro and Bambara Groundnut. In: Sustainable Agriculture Reviews Volume 13. Springer Switzerland. 275-290. https://doi.org/10.1007/978-3-319-00915-5_9

MEAD R and WILLEY R (1980) The concept of a 'land equivalent ratio'and advantages in yields from intercropping. Exp. Agric. 16 (3) 217-228. https://doi.org/10.1017/S0014479700010978

MERMOUD A, TAMINI T and YACOUBA H (2005) Impacts of different irrigation schedules on the water balance components of an onion crop in a semi-arid zone. Agric. Water Manage. 77 (1) 282 295. https://doi.org/10.1016/j.agwat.2004.09.033

MOUSAVI SR and ESKANDARI H (2011) A general overview on intercropping and its advantages in sustainable agriculture. J. Appl. Environ. Biol. Sci. 1 (11) 482-486.

MOYA P, HONG L, DAWE D and CHONGDE C (2004) The impact of on-farm water saving irrigation techniques on rice productivity and profitability in Zhanghe Irrigation System, Hubei, China. Paddy Water Environ. 2 (4) 207-215. https://doi.org/10.1007/ s10333-004-0063-2

MULBAH QS (2010) Effect of simulating flooding pattern on nitrogen management in rice (Oryza sativa l.) production. MSc thesis, University of KwaZulu-Natal Pietermaritzburg.

MUSAZURA W, ODINDO A, BAME I and TESFAMARIAM E (2015a) Effect of irrigation with anaerobic baffled reactor effluent on Swis chard (Beta vulgaris cicla.) yield, nutrient uptake and leaching. J. Water Reuse Desalin. 5 (4) 592-609. https://doi.org/10.2166/ wrd.2015.011

MUSAZURA W, ODINDO A, BAME I and TESFAMARIAM EH (2015b) Effect of irrigation with anaerobic baffled reactor effluent on Swiss chard (Beta vulgaris cicla) yield, nutrient uptake and leaching. J. Water Reuse Desalin. 5 (4) 592-609. https://doi.org/10.2166/ wrd.2015.011

OKWUOWULU P, ASIEGBU J and NWAKO W (2000) Effect of row intercropping of minisett cocoyam/rice on tuber/grain yield and productivity in southeastern Nigeria. J. Sustainable Agric. Environ. 2 (2) 214-225.

OLIVER M, TALUKDER M and AHMED M (2008) Alternate wetting and drying irrigation for rice cultivation. J. Bangladesh Agric. Univ. 6 (2) 409-414. https://doi.org/10.3329/jbau.v6i2.4841

PASCUAL VJ and WANG Y-M (2016) Impact of water management on rice varieties, yield, and water productivity under the system of rice intensification in southern Taiwan. Water 9 (1) 3. https://doi org/10.3390/w9010003

PRICE AH, NORTON GJ, SALT DE, EBENHOEH O, MEHARG AA, MEHARG C, ISLAM MR, SARMA RN, DASGUPTA T and
ISMAIL AM (2013) Alternate wetting and drying irrigation for rice in Bangladesh: Is it sustainable and has plant breeding something to offer? Food Energ. Secur. 2 (2) 120-129. https://doi.org/10.1002/fes3.29

RUÍZ-SÁNCHEZ M, ARMADA E, MUÑOZ Y, DE SALAMONE IEG, AROCA R, RUÍZ-LOZANO JM and AZCÓN R (2011) Azospirillum and arbuscular mycorrhizal colonization enhance rice growth and physiological traits under well-watered and drought conditions. J. Plant Physiol. 168 (10) 1031-1037. https://doi.org/10.1016/j. jplph.2010.12.019

RUSINAMHODZI L, CORBEELS M, NYAMANGARA J and GILLER KE (2012) Maize-grain legume intercropping is an attractive option for ecological intensification that reduces climatic risk for smallholder farmers in central Mozambique. Field Crops Res. 136 12-22. https://doi.org/10.1016/j.fcr.2012.07.014

SAGOE R, BAM R, MANU-ADUEING J, HALEEGOAH J, TETTEH J, OSEI J and SAFO-KANTANKA O (2004) Evaluation of performance of rice (Oryza sativa) and taro (Colocasia esculenta) in a mixed cropping system. Ghana J. Agric. Sci. 37 (1) 49-57. https:// doi.org/10.4314/gjas.v37i1.2079

SECK PA, TOLLENS E, WOPEREIS MCS, DIAGNE A and BAMBA I (2010) Rising trends and variability of rice prices: Threats and opportunities for sub-Saharan Africa. Food Polic. 35 (5) 403-411. https://doi.org/10.1016/j.foodpol.2010.05.003

SERAN TH and BRINTHA I (2010) Review on maize based intercropping. J. Agron. 9 (3) 135-145. https://doi.org/10.3923/ ja.2010.135.145

SINGH S, HABERL R, MOOG O, SHRESTHA RR, SHRESTHA P and SHRESTHA R (2009) Performance of an anaerobic baffled reactor and hybrid constructed wetland treating high-strength wastewater in Nepal-A model for DEWATS. Ecol. Eng. 35 (5) 654-660. https:// doi.org/10.1016/j.ecoleng.2008.10.019

TAKIM F (2012) Advantages of maize-cowpea intercropping over sole cropping through competition indices. J. Agric. Biodivers. Res. 1 (4) 53-59.

TAN X, SHAO D, LIU H, YANG F, XIAO C and YANG H (2013) Effects of alternate wetting and drying irrigation on percolation and nitrogen leaching in paddy fields. Paddy Water Environ. 11 (1-4) 381-395. https://doi.org/10.1007/s10333-012-0328-0

TOZE S (2006) Reuse of effluent water-benefits and risks. Agric. Water Manage. 80 (1) 147-159. https://doi.org/10.1016/j.agwat.2005.07.010

TUMUHIMBISE R (2015) Plant spacing and planting depth effects on corm yield of taro (Colocasia esculenta (L.) Schott). J. Crop Improvement 29 (6) 747-757. https://doi.org/10.1080/15427528.201 5.1083498

YANG C, HUANG G, CHAI Q and LUO Z (2011) Water use and yield of wheat/maize intercropping under alternate irrigation in the oasis field of northwest China. Field Crops Res. 124 (3) 426-432. https:// doi.org/10.1016/j.fcr.2011.07.013

YAO F, HUANG J, CUI K, NIE L, XIANG J, LIU X, WU W, CHEN M and PENG S (2012) Agronomic performance of high-yielding rice variety grown under alternate wetting and drying irrigation. Field Crops Res. 126 16-22. https://doi.org/10.1016/j.fcr.2011.09.018

YE Y, LIANG X, CHEN Y, LIU J, GU J, GUO R and LI L (2013) Alternate wetting and drying irrigation and controlled-release nitrogen fertilizer in late-season rice. Effects on dry matter accumulation, yield, water and nitrogen use. Field Crops Res. 144 212-224. https:// doi.org/10.1016/j.fcr.2012.12.003

ZHANG F, SHEN J, ZHANG J, ZUO Y, LI L and CHEN X (2010a) Rhizosphere processes and management for improving nutrient use efficiency and crop productivity: implications for China. Adv. Agron. 107 1-32. https://doi.org/10.1016/S0065-2113(10)07001-X

ZHANG H, CHEN T, WANG Z, YANG J and ZHANG J (2010b) Involvement of cytokinins in the grain filling of rice under alternate wetting and drying irrigation. J. Exp. Bot. 61 (13) 3719-3733. https:// doi.org/10.1093/jxb/erq198

ZHU G, ZOU R, JHA AK, HUANG X, LIU L and LIU C (2015) Recent developments and future perspectives of anaerobic baffled bioreactor for wastewater treatment and energy recovery. Crit. Rev. Environ. Sci. Technol. 45 (12) 1243-1276. https://doi.org/10.1080/10 643389.2014 .924182 